\title{
Application of biological products in strawberry cultivars to control Botrytis cinerea
}

\author{
Aplicação de produtos biológicos em cultivares de morangueiro visando o controle de Botrytis \\ cinerea
}

\section{Aplicación de productos biológicos en cultivares de fresa para el control de Botrytis cinerea}

Csaignon Mariano Caproni

ORCID: https://orcid.org/0000-0003-1855-8312 Agricultural Research Company of Minas Gerais, Brazil

E-mail: csaignon@gmail.com

Filipe Almendagna Rodrigues

ORCID: https://orcid.org/0000-0003-2433-4374

Federal University of Lavras, Brazil

E-mail: filipealmendagna@yahoo.com.br

Renata Alves Lara Silva Rezende

ORCID: https://orcid.org/0000-0001-6410-9716 Federal University of Lavras, Brazil E-mail: renata_vg@yahoo.com.br

Alan William Vilela Pomella

ORCID: https://orcid.org/0000-0002-8981-4443

Lallemand Plant Care, USA

E-mail: apomella@lallemand.com

Moacir Pasqual

ORCID: https://orcid.org/0000-0001-5612-9186

Federal University of Lavras, Brazil

E-mail: mpasqual@ufla.br

\begin{abstract}
The objective of this work was to evaluate three strawberry cultivars in an organic production system combined with the application of biological products via leaf for the control of Botrytis cinerea aiming at increasing fruit productivity and quality. The experimental design was randomized block, in a $5 \times 3$ factorial scheme, consisting of four products and three cultivars. The treatments consisted of the biological products Onix (Bacillus methylotrophicus), Quartz (Bacillus amyloliquefaciens), Botector (Aureobasidium pullulans), Prestop (Gliocladium catenatum) and control (water application in the plot) in combination with three strawberry cultivars (Cristal, Monterey and Pircinque). Through the results it was possible to observe the superiority of the cultivar Cristal in the total fruit production when compared to the cultivars Monterey and Pircinque. The biological products Onix, Quartz and Botector provided higher total strawberry production. The recommended cultivar for planting in the southern region of Minas Gerais is Pircinque due to the high levels of soluble solids and total sugars observed. The application of biological products was effective in controlling Botrytis cinerea.
\end{abstract}

Keywords: Fragaria X ananassa Duch.; Microorganisms; Fungi.

\section{Resumo}

O objetivo deste trabalho foi avaliar três cultivares de morangueiro em sistema de produção orgânica aliada a aplicação de produtos biológicos via foliar para o controle de Botrytis cinerea, possibilitando aumento da produtividade e qualidade de frutos. O delineamento experimental foi em blocos casualizados, em esquema fatorial $5 \times 3$, constituído de quatro produtos e três cultivares. Os tratamentos foram constituídos pelos produtos biológicos Onix (Bacillus methylotrophicus), Quartz (Bacillus amyloliquefaciens), Botector (Aureobasidium pullulans), Prestop (Gliocladium catenatum) e controle (aplicação de água) em combinação com três cultivares de morangueiro (Cristal, Monterey e Pircinque). Através dos resultados observou-se superioridade da cultivar Cristal na produção de frutos quando comparada as cultivares Monterey e Pircinque. Os produtos biológicos Onix, Quartz e Botector proporcionaram maiores produções totais de morango. A cultivar recomendada para o plantio na região Sul de Minas Gerais é a Pircinque devido aos altos teores de sólidos solúveis e açúcares totais observados. A aplicação dos produtos biológicos foram efetivos no controle do Botrytis cinerea.

Palavras-chave: Fragaria X ananassa Duch.; Microrganismos; Fungos. 


\section{Resumen}

El objetivo de este trabajo fue evaluar tres cultivares de fresa en un sistema de producción ecológico combinado con la aplicación de productos biológicos vía hoja para el control de Botrytis cinerea, lo que permite incrementar la productividad y la calidad del fruto. El diseño experimental fue en bloques al azar, en un esquema factorial 5x3, compuesto por cuatro productos y tres cultivares. Los tratamientos consistieron en los productos biológicos Onix (Bacillus methylotrophicus), Quartz (Bacillus amyloliquefaciens), Botector (Aureobasidium pullulans), Prestop (Gliocladium catenatum) y control (aplicación de agua) en combinación con tres cultivares de fresa (Cristal, Monterey y Pircinque). A través de los resultados se observó superioridad del cultivar Cristal en la producción de frutos con respecto a los cultivares Monterey y Pircinque. Los productos biológicos Onix, Quartz y Botector proporcionaron mayores rendimientos totales de fresa. El cultivar recomendado para plantar en la región sur de Minas Gerais es Pircinque debido a los altos niveles de sólidos solubles y azúcares totales observados. La aplicación de productos biológicos fue eficaz en el control de Botrytis cinerea.

Palabras clave: Fragaria X ananassa Duch.; Microorganismos; Hongos.

\section{Introduction}

Strawberry production in a sustainable way has been gaining ground in the markets, since consumers are looking for healthier foods that are less aggressive to the environment (Caproni et al., 2013). Sustainable agriculture is the practice that meets current and long-term needs for the production of food with fibers and other societal needs, while maximizing the benefits obtained through the conservation of natural resources to maintain other services and functions of the ecosystem (Tilman et al., 2002).

Due to the economic and social importance of strawberry cultivation for the south region of Minas Gerais, adequate management, higher productivity and quality of strawberry fruits have been sought, as well as the control of pathogens that have been causing damage to crops.

The strawberry is a very perishable fruit, making it susceptible to attack by microorganisms, causing significant losses in the post-harvest (Cantillano \& Silva, 2010). Gray mold (Botrytis cinerea) is an important and frequent pathogen in strawberry fruits, affecting petioles, flower buds, petals and peduncles in atypical favorable environments (Braun $\&$ Sutton, 1978). This fungus causes great damage to strawberry producers in the South of Minas Gerais, causing rot in strawberry fruits when they are still in the field, leaving the fruits unfit for consumption. In addition, this disease can cause losses of 20 to $30 \%$ in production depending on the high humidity and rainy season.

Botrytis cinerea is able to survive in the soil with organic matter or as a compact mass of hyphae. After the production of conidiophores by hyphae, in diseased plants, they produce conidia that travel through the air infecting several other hosts. Its germination is favored by temperature around 22 to $25^{\circ} \mathrm{C}$ and relative humidity from 90 to $100 \%$. The colonization of the tissues is very fast after its infiltration, presenting ample sporulation and originating other cycles of the disease (Tofoli et al., 2011).

The attack of pathogens on the strawberry can be more severe in more susceptible cultivars. As a result, there is a great demand from organic producers for alternative products to conventional ones, mainly in the use of natural microorganisms aiming at the sustainable control of pathogens and the absence of toxic residues for the environment.

According to Leroch et al. (2013), the frequent use of fungicide to control the pathogen is increasingly questioned in strawberry production due to the increasing occurrence of Botrytis cinerea resistance. In addition, the fungicide presents potential risks to the environment and human health (Hauschild, 2012).

However, in order to control gray mold, the producer must improve the conditions of aeration and adequate spacing between the plants and use of well-drained soils. In addition, planting in very steep places or terrain with depression should be avoided, as rainwater accumulation or excess irrigation water may occur, increasing the severity of the disease (Choquer et al., 2007).

The objective of this work was to evaluate three strawberry cultivars in an organic production system combined with 
the application of biological products via leaf for the control of Botrytis cinerea aiming at increasing productivity and fruit quality.

\section{Methodology}

The experiment was conducted on a private property located in the municipality of Pouso Alegre - MG, Brazil. The municipality has a Cwa-type climatic classification, that is, a warm temperate climate (mesothermal), with dry winter and rainy summer, with an average annual temperature of around $19.2^{\circ} \mathrm{C}$, average relative humidity of $75 \%$, total annual rainfall of approximately $1744 \mathrm{~mm}$ and an average altitude of $1100 \mathrm{~m}$, with a predominance of undulating relief (Köppen, 1948).

The experiment was carried out in an overlapping bed, with a low tunnel and a transparent milky plastic cover to protect the plants, avoiding dew in the night and excessive rainfall in the winter and providing better disease control. The carriers were covered with dehydrated hay or grass to prevent the splash of rain droplets on the leaves and accumulation of water between the beds, as well as to inhibit the appearance of outbreaks of pathogens inoculants on leaves and fruits.

The beds were prepared 30 days before planting and had the following measures: $1.20 \mathrm{~m}$ wide and $0.25 \mathrm{~m}$ high. In the beds, $250 \mathrm{~g} \mathrm{~m}^{2}$ castor cake, $460 \mathrm{~g} \mathrm{~m}^{2}$ natural phosphate, $5.0 \mathrm{~L} \mathrm{~m}^{2}$ organic compost and $200 \mathrm{~g} \mathrm{~m}^{2}$ bone meal were applied. After the application of the inputs, the incorporation was carried out with the aid of a rotary hoe coupled to a tractor.

Strawberry seedlings were removed from the nursery and planted in the production area in April 2018. After the seedlings were caught in the field, black mulching was done to prevent weed infestation in beds and between plants. The drip irrigation system was located, allowing plant irrigation and organic fertirrigation.

The treatments consisted of the application of four natural biological products (Onix, Quartz, Botector, Prestop), containing, respectively, Bacillus methylotrophicus, Bacillus amyloliquefaciens, Aureobasidium pullulans, Gliocladium catenatum isolates and the control with water application in three strawberry cultivars (Cristal, Monterey and Pircinque).

The experimental design was in randomized blocks, in a $5 \times 3$ factorial scheme, consisting of 15 treatments and three replications, totaling 45 plots. Each plot was composed of 15 plants and occupied an area of $1.80 \mathrm{~m}^{2}$, with a spacing of $0.30 \mathrm{x}$ $0.40 \mathrm{~m}$, with three planting lines.

The products were applied weekly via leaf after planting the seedlings, throughout the productive cycle (seven months). The plants of each plot and the fruits that showed symptoms of gray mold were diagnosed and their characteristics monitored during the productive performance of the seedling in the field.

The harvest of the first ripe fruits started 70 days after planting (second half of the month of June), and ended at the end of the month of October 2018.

At the end of the experiment, the estimated total production in $\mathrm{kg}$ ha-1, total production $(\mathrm{g})$, total number of commercial fruits and symptoms of gray mold (Botrytis cinerea) per plot and analysis of the chemical composition of the internal part of the fruit were calculated. Soluble solids ( ${ }^{\circ}$ Brix), total titratable acidity (\%) and total sugars (\%) were also evaluated.

The data obtained were subjected to the test of normality and homogeneity of variance and the means were compared using the Scott-Knott test at 5\% probability using the SISVAR statistical software (Ferreira, 2011).

\section{Results and Discussion}

Significant interaction was observed between the application of biological products and strawberry cultivars in relation to the number of fruits with symptoms of gray mold (Botrytis cinerea) and total sugars. Total strawberry production was higher in cultivars Cristal and Pircinque (Figure 1A). Meanwhile, the application of Onix (Bacillus methylotrophicus), 
Quartz (Bacillus amyloliquefaciens) and Botector (Aureobasidium pullulans) provided greater strawberry production (Figure 1B).

Figure 1. Total fruit production among in relation to the Application of biological products in different strawberry cultivars. A and C - Total fruit production; B and D - Number of fruits.
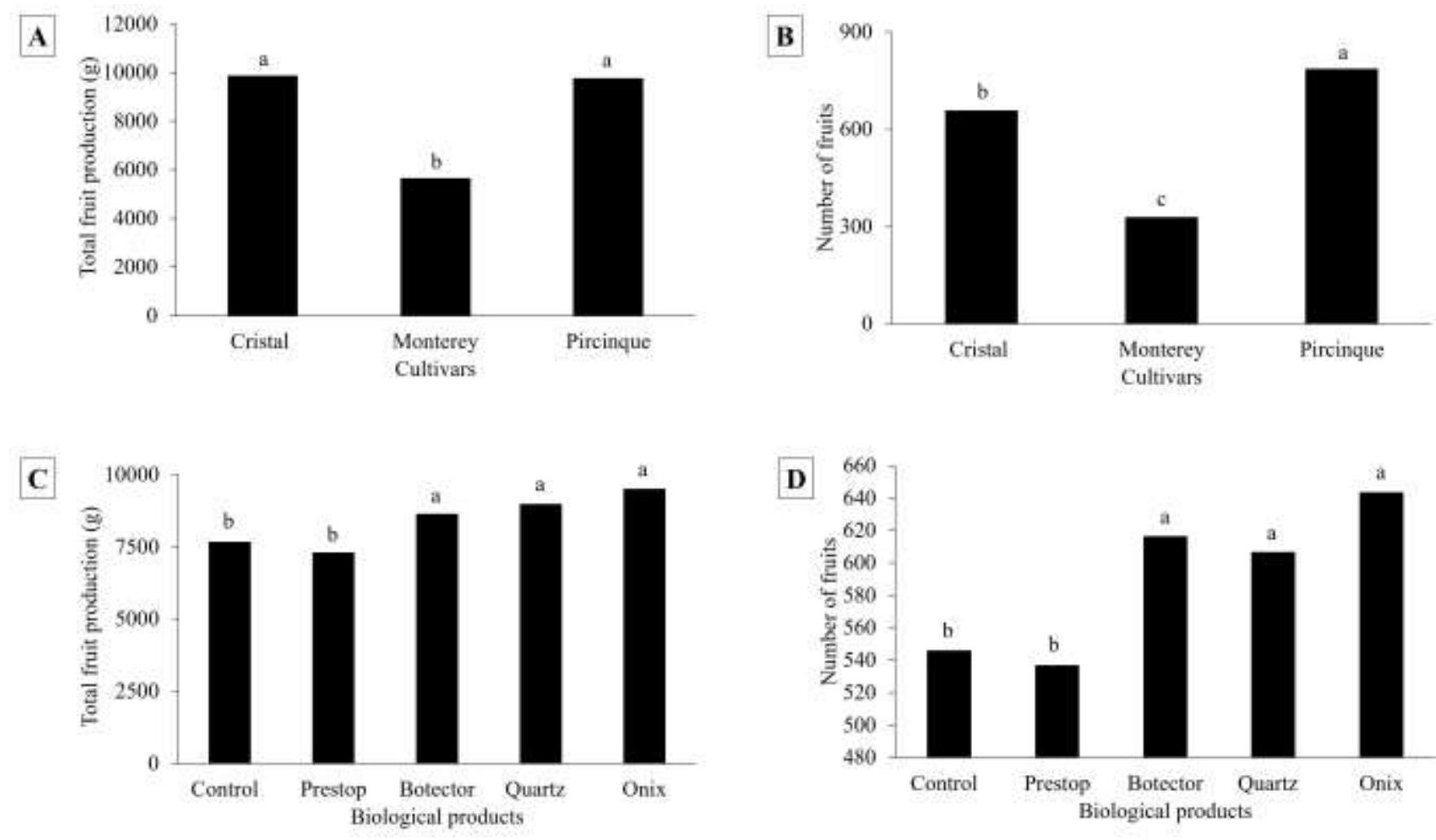

Source: Authors.

Regardless of the cultivar evaluated, the application of Onix provided an increase of $24.04 \%$ in the total production of fruits in relation to the control that received only water. On the other hand, the application of Quartz allowed an increase of $17.19 \%$ when compared to the control. In addition, the application of Botector caused an increase in production of $12.75 \%$ and Prestop a reduction of $4.91 \%$ when compared to the control (Figure 1B).

As for the total number of fruits produced, the cultivar Pircinque was the one with the highest production (Figure 1C). Regarding the product used, the largest production occurred with the application of Onix, Botector and Quartz (Figure 1D).

Significant interaction was observed between the application of biological products and strawberry cultivars for the content of soluble solids and total acidity.

Higher $\mathrm{pH}$ values, soluble solids and total sugars were found in the cultivar Pircinque (Figure 2 and Table 1), being possible to observe the superiority of the cultivar Pircinque in relation to Cristal and Monterey. The content of soluble solids is a characteristic of interest for the sale of fresh fruits, as the consumer market's preference is for sweet fruits (Conti et al., 2002). 
Figure 2. Average $\mathrm{pH}$ values, soluble solids (SS), total titratable acidity (TTA) in g citric acid/100 g of pulp and total sugars (TS) in different cultivars.

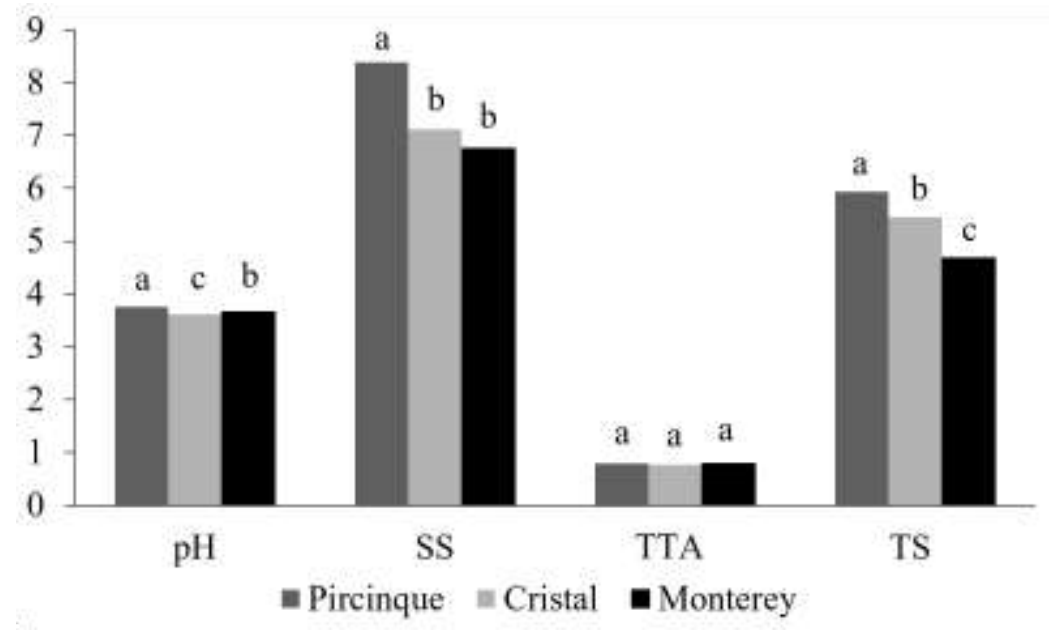

Source: Authors.

Table 1. Total sugars and number of fruits with Botrytis cinerea symptoms in different strawberry cultivars in relation to the application of biological products.

\begin{tabular}{|c|c|c|c|}
\hline \multirow{3}{*}{ Products } & \multicolumn{3}{|c|}{ Total sugars (\%) } \\
\hline & \multicolumn{3}{|c|}{ Cultivars } \\
\hline & Cristal & Monterey & Pircinque \\
\hline Onix & $5,64 \mathrm{aA}$ & 4,69 bA & $4,93 \mathrm{bB}$ \\
\hline Quartz & $5,48 \mathrm{bA}$ & $5,40 \mathrm{bA}$ & $6,07 \mathrm{aA}$ \\
\hline Botector & $5,16 \mathrm{bA}$ & $4,74 \mathrm{bA}$ & $5,80 \mathrm{aA}$ \\
\hline Prestop & $5,35 \mathrm{bA}$ & $4,53 \mathrm{cA}$ & $6,38 \mathrm{aA}$ \\
\hline Control & $5,63 \mathrm{aA}$ & 4,93 aA & $6,48 \mathrm{aA}$ \\
\hline \multirow[t]{2}{*}{$\mathrm{CV}(\%)$} & \multicolumn{3}{|c|}{6,80} \\
\hline & \multicolumn{3}{|c|}{ Number of fruits with Botrytis cinerea symptoms } \\
\hline \multirow{2}{*}{ Products } & \multicolumn{3}{|c|}{ Cultivars } \\
\hline & Cristal & Monterey & Pircinque \\
\hline Onix & $80,33 \mathrm{cB}$ & 8,66 aA & $40,00 \mathrm{bA}$ \\
\hline Quartz & $33,00 \mathrm{bA}$ & 8,66 aA & $67,66 \mathrm{cB}$ \\
\hline Botector & $28,66 \mathrm{aA}$ & $7,33 \mathrm{aA}$ & $56,66 \mathrm{bB}$ \\
\hline Prestop & $26,66 \mathrm{bA}$ & 8,66 bA & $41,33 \mathrm{aA}$ \\
\hline Control & $37,00 \mathrm{bA}$ & $9,67 \mathrm{aA}$ & $62,00 \mathrm{cB}$ \\
\hline $\mathrm{CV}(\%)$ & & 38,67 & \\
\hline
\end{tabular}

Means followed by the same letter in uppercase and lowercase in line in the column do not differ by Scott-Knott test $(\mathrm{P} \leq 0,05)$. Source: Authors. 
Among the cultivars evaluated, Pircinque is the most suitable for consumption of fresh fruits, due to high index ( ${ }^{\circ}$ Brix) and total sugars, presenting great potential and relevance for expansion in the national market, with medium standard size fruits, very red in color when ripened, very sweet and firm flesh. In addition, this cultivar is characterized by being vigorous, rustic and has fruits with a conical, elongated and sweet shape, and can be part of the strawberry marketing routes aiming at the production of fruits of high sweetness and quality (Mennone et al., 2012).

For the control of Botrytis cinerea in strawberry fruits of the cultivar Pircinque, the most effective treatments were the application of Prestop and Onix. In the cultivar Monterey there was no significant difference between the products applied. On the other hand, the application of Onix in the cultivar Cristal was not effective in controlling Botrytis cinerea in strawberry fruits (Table 1). Gray mold represents an important and frequent disease in strawberry fruits.

\section{Conclusion}

Cultivars Cristal and Pircinque combined with the application of the products Onix, Quartz and Botector provided higher total strawberry yields.

Prestop and Onix products were more effective in controlling Botrytis cinerea in the fruits of the cultivar Pircinque. The cultivar Pircinque should be recommended for planting by strawberry producers due to the high levels of soluble solids and total sugars that the fruits have, in addition to the great potential and relevance for expansion in the national market with medium-sized fruits and a very red color when ripe, sweet flavor and firm pulp.

\section{References}

Braun, P. G. \& Sutton, J. C. (1978). Infection cycles and population dynamics of Botrytis cinerea in Strawberry leaves. Canadian of Plant Pathology, 10, 133141.

Cantillano, R. F. F. \& Silva, M. M. (2010). Manuseio pós-colheita de morangos. Pelotas: Embrapa Clima Temperado. 36p.

Caproni, M. et al. (2013). Produção sustentável de morangueiro. Revista Agrogeoambiental, 5(3), 91-98.

Choquer, M. et al. (2007). Botrytis cinerea virulence factors: New insights into a necrotrophic and polyphageous pathogen. Federation of European Microbiological Societies Microbiology Letters, 277(1), 1-10.

Conti, J. H., Minami, K. \&Tavares, F. C. A. (2002). Produção e qualidade de frutos de morango em ensaios conduzidos em Atibaia e Piracicaba. Horticultura Brasileira, 20, 10-17.

Ferreira, D. F. (2011). SISVAR: um sistema computacional de análise estatística. Ciência \& Agrotecnologia, 35, $1039-1042$.

Hauschild, R. (2012). Safety and regulation of microbial pest control agents and microbial plant growth promoters - Introduction and overview. In. SUNDH et al., eds. Beneficial microorganisms in agriculture, food and the environment. Safety assessment and regulation, 67-71.

Köppen, W. (1948). Climatologia: con un estudio de los climas de la tierra. Fondo de Cultura Economica. México.

Leroch, M. et al. (2013). Gray mol population in German strawberry fields are resistant to multiple Fungicides and dominated by a model clade closely related to Botrytis cinerea. Applied and Environmental Microbiology, 79(1), 159-167.

Mennone, C., Quinto, G. R. \& Danzi, C. (2012). Innovazione técnica e varietale nell'areale Metapontino. Rivista di Frutticoltura e di Ortofloricoltura, 6, 2628 .

Tilman, D. et al. (2002). Agricultural sustainability and intensive production practices. Nature, 418, 671-677.

Töfoli, J. G. et al. (2011). Botrytis sp. em espécies hortícolas: hospedeiros, sintomas e manejo. Instituto Biológico, 73(1), 11-20. 